http://dx.doi.org/10.19183/how.24.2.345

\title{
Exploring English Teachers' Perceptions About Peer- Coaching as a Professional Development Activity of Knowledge Construction
}

\section{Explorando las percepciones de los profesores de inglés acerca de la asesoría entre pares como una actividad de desarrollo profesional de construcción de conocimiento*}

\author{
Adriana Castañeda-Londoño \\ acastanedal@correo.udustrital.edu.co \\ Universidad Distrital Francisco José de Caldas, Bogotá, Colombia
}

Teachers' knowledge and how they construct it is an area that deserves attention when it comes to producing fruitful professional development practices. This small-scale action research aims at identifying the perceptions of three teachers in a private language center about peer-coaching and their actual construction of knowledge in a peer-coaching activity. Data were collected through two narratives and the transcription of recorded conversations among participants after the observation of their classes. The results suggest that before peer-coaching teachers held three types of perceptions towards observation and feedback: a cautious approach, an identity tension approach, and a celebratory approach. After peer-coaching one sees that two perceptions emerged: observation and feedback entail, on the one hand, high anxiety about teachers' selfimage; and on the other, observation and feedback show a deep sense of their selves.

Key words: Peer-coaching, professional development, self, teacher knowledge.

El conocimiento de los profesores y cómo ellos lo construyen es un área que merece atención cuando se desea producir prácticas de desarrollo profesional fructíferas. La investigación-acción a pe-

Received: January 5, 2017. Accepted: June 7, 2017.

How to cite this article (APA 6th ed.):

Castañeda-Londoño, A. (2017). Exploring English teachers' perceptions about peer-coaching as a professional development activity of knowledge construction. HOW, 24(2), 80-101. http://dx.doi.org/10.19183/ how.24.2.345.

This article is licensed under a Creative Commons Attribution-NonCommercial-NoDerivatives 4.0 International License. License Deed can be consulted at http://creativecommons.org/licenses/by-nc-nd/4.0/. 
queña escala reportada aquí tiene como objetivo mostrar las percepciones de tres profesores en un centro de idiomas privado acerca de la asesoría entre pares y el conocimiento construido por los participantes en este este ejercicio. Los datos se recolectaron a través de dos narrativas y la transcripción de la grabación de interacciones de los profesores después de la observación de clase. Los datos sugieren que antes de la asesoría entre pares los profesores tenían tres percepciones acerca de la observación y la retroalimentación: una percepción de enfoque cauteloso, otra de enfoque de tensión identitaria y una celebratoria de la observación y la retroalimentación. Después de participar en la asesoría entre pares dos percepciones emergieron: la observación y la retroalimentación implican por un lado ansiedad acerca de la auto-imagen del profesor, por otro lado, representan un profundo sentido de su yo.

Palabras clave: asesoría entre pares, conocimiento docente, desarrollo profesional.

\section{Introduction}

For several years, I worked for a top-quality language center. This institution has a wellstructured supervision system that aims at assuring that teachers abide by specific classroom teaching principles. Such principles are related to (a) having clear objectives for each lesson, (b) developing adequate classroom management, (c) fostering language skills development, (d) engaging students in interaction, (e) providing learning strategies instruction, and (f) using different assessment techniques of students' performances. The language center supervisor assesses to what extent these principles are achieved by mean of observations, meetings with teachers, and checklists. This process is intended first to evaluate teachers' application of the institution principles and second, to help teachers reflect upon their performances and improve their professional practices.

I had both experiences: being a teacher and a supervisor. These roles led me to pursue an interest in proposing alternative ways to foster professional development among my colleagues. In particular, a survey applied to teachers in 2014 by the supervision team caught my attention because it revealed some tensions with the supervision system. Thus, as a teacher researcher I put forward the exploration of peer-coaching as a means to enhance teachers' professional growth stemming from teachers' own perceptions that supervisory practices may cause some sort of tension between complying with the regulations and developing teachers' own autonomy.

In general terms, the concept of peer-coaching was used in this small-scale research project as stated by Richards and Farrell (2005); that is, a teacher and a colleague who plan to collaboratively explore their teaching practices. In the next lines, I will explain where the interest in peer-coaching comes from.

In the context in which this small-scale action research took place; having a structured supervision system for teacher regulation that aims at improving the teaching practices 
appears to have positive outcomes. One of them is enriching the teachers' own views of the classroom practices with an outsider's perspective. Nonetheless, teachers' supervision does not escape criticism. As a matter of fact, research by Hişmanoğlu and Hişmanoğlu (2010) supports evidence of contending positions regarding teaching supervision. Their study of 50 English, American, and Turkish-Cypriot teachers' perceptions towards educational supervision shows that teachers approve of supervision in regard to educational leadership and human relations, although they oppose the supervision when it comes to restraining their free will. Richards and Farrell (2005) also point out the drawbacks that a supervisory observation poses. Four main issues are highlighted: observations are intimidating and prescriptive, checklists evaluate many items, and assessment is observer-based. Thus, this system may be a way to impose pedagogical and methodological kinds of knowledge on teachers who, in turn, end up doing what is policed and not developing a repertoire of their own. These ideas resonate with the survey previously mentioned that was applied to 24 teachers in 2014 whose intention was to evaluate the supervision system at that time. The survey inquired about key elements of the system, namely:

a. The positive and negative aspects of supervision.

b. Teachers' opinions about the checklist used for classroom observation.

Backed up by the survey, I contend that peer-coaching may serve as a professional development activity that could provide a perspective different from that of the supervisory practice in the English language center described here. This center had historically had supervision practices and no other sort of feedback provision activity for teachers working there. Teachers' main responses about the supervision system are shown in Table 1.

Table 1. Summary of Positive and Negative Aspects of Supervision

\begin{tabular}{|l|l|}
\hline \multicolumn{1}{|c|}{ Positive aspects } & \multicolumn{1}{|c|}{ Negative aspects } \\
\hline "Supervisors show our strengths and weaknesses" & $\begin{array}{l}\text { "Sometimes, supervisors are more } \\
\text { likely to focus more on the weaknesses } \\
\text { than in the good practices" }\end{array}$ \\
\hline $\begin{array}{l}\text { "Having an 'outside' point of view of our classes } \\
\text { gives us good feedback about our performance" }\end{array}$ & $\begin{array}{l}\text { "Some practices can be adopted just to } \\
\text { satisfy the supervisors' style to teach, } \\
\text { but not as a personal conviction" }\end{array}$ \\
\hline $\begin{array}{l}\text { "The supervision] allows the exchange of practices } \\
\text { and strategies between the supervisor and the teacher" }\end{array}$ & $\begin{array}{l}\text { "Supervisors want teachers' classes } \\
\text { to resemble their practices" }\end{array}$ \\
\hline
\end{tabular}


Exploring English Teachers' Perceptions About Peer-Coaching as a Professional Development Activity of Knowledge Construction

\begin{tabular}{|l|l|}
\hline \multicolumn{1}{|c|}{ Positive aspects } & \multicolumn{1}{|c|}{ Negative aspects } \\
\hline $\begin{array}{l}\text { "Supervisors provide good models, bibliographies, and } \\
\text { webpages for teachers to consult and try to apply" }\end{array}$ & $\begin{array}{l}\text { "There are not possibilities to observe } \\
\text { supervisors teaching to learn from them" }\end{array}$ \\
\hline "[There is] accurate feedback for teachers" & $\begin{array}{l}\text { "Not all the (observation) checklist } \\
\text { can be covered completely } \\
\text { conscientiously in two classes" }\end{array}$ \\
\hline
\end{tabular}

Note. Excerpts have been transcribed verbatim.

The extracts in Table 1 show the complexity of teachers' and supervisors' power relations (Norton, 1995). Teachers' excerpts acknowledge the themes of a dialogue among teachers and supervisors of which reflection, strengths, weaknesses, up-to-date knowledge, and improvement are the main components. However, the extracts also pinpoint the tensions teachers experience for not having enough agency (Norton, 1995) leading them to take actions that occur from a top-down procedure and not as a teachers' initiative. Similarly, the participants highlight other items that increase tensions such as the perceived overemphasis on weaknesses and lack of opportunities to observe the supervisors' own lessons to get new ideas. Thus, proposing a peer-coaching practice among fellow teachers would provide a different perspective towards power as more horizontal relations are likely to occur in those interactions.

Finally, when teachers were asked to suggest improvements in the supervision system, three main aspects were mentioned, namely, (a) the use of expertise as a source of valid knowledge, (b) the observation of other teachers' classes, and (c) formative assessment/ feedback before the actual supervisor's summative evaluation. The following excerpts were selected as examples of the most salient themes mentioned above:

I'd like to see more activities applied by other teachers. (T1)

I know that all the tasks are useful and meaningful for our teaching process but it seems to be overwhelming and sometimes we probably just comply with them because we have to in order for us to have a grade. (T2)

I think it is healthy and makes a teacher more confident to be observed and be given feedback prior to the formal evaluation with the checklist. Sometimes, the pressure of the evaluation... makes impossible for teachers to comply with all the aspects of the checklist. (T3)

[Supervisors] should take into account teacher's ideas and experiences and how they can adapt those ideas in class in a better way. (T4) 
In sum, teachers appeared to agree that more collaboration among teachers and less pressure would make a difference in the supervision system. Strategies like observing other teachers, having prior formative assessment before the actual summative one, or considering their own experiences could serve the purpose of improving the supervision approach. Although how the supervision system improved as a result of peer-coaching goes beyond the scope of this research, the findings suggest that instances of collaboration, formative assessment and consideration of teachers' knowledge do occur while participating in peercoaching and could eventually prepare teachers for supervisory practices.

In this inquiry, the survey discussed above helped justify the need for finding out alternative perspectives towards teachers' assessments of their professional practices that showed other possibilities towards teaching while fostering collaborative relations among teachers. As a teacher researcher, statements like: "I'd like to see more activities applied by other teachers" or "some practices can be adopted just to satisfy the supervisors' style to teach, but not as a personal conviction" strike a chord and led me to develop a proposal of peer-coaching.

\section{Research Question}

Joyce and Showers (as cited in Malu, 2015) state the three factors that foster teacher's change are precisely observation, feedback, and practice. Such a cycle is expected to "empower and promote teacher's change" (p. 14). However, Malu (2015) suggests that the teacher who is being peer-coached is the one who finds out the purpose of observing his/her class, raises the concerns that he/she has and spots the principles/key areas that the teacher wants the observer to tackle. These ideas are backed up in Richards and Farrell (2005) who suggest that prior to the observation of a colleague's class, the teacher who is being observed should set his/her goals. The coach or critical friend makes suggestions and the observed teacher still holds the power to change what he/she deems necessary to change. All these things considered, I sought to focus my attention on the collaborative relations that could emerge at the work place among colleagues as well as the "on the job learning opportunities" (Parise \& Spillane, 2010, p. 324). Thus, the central question that I addressed in this small-scale action research is: What are teachers' perceptions regarding class observation and feedback before and after participating in peer-coaching?

Four reasons guided the study of peer-coaching. First, in an exploration of the extant literature regarding teacher supervision systems, Hişmanoğlu and Hişmanoğlu (2010) suggest that the ever-lasting contending nature of supervision practices and teachers' beliefs and actions require sustained policies that could lead to real changes in teaching. Such a view may hold true considering that teachers' personal epistemologies are deeply-rooted and are result 
of their own history as learners and teachers. Thus, changes in teaching practices may take long and should be self-initiated. Otherwise, resistances to impositions will abound.

Second, Gallucci, van Lare, Yoon, and Boatright (2010) and Parise and Spillane (2010) suggest that learning experiences that occur at the workplace, meaning learning that happens with teacher-colleagues, still lacks empirical evidence that supports its impact. For Parise and Spillane, on the job learning opportunities can be of two types: (a) formal learning experiences and graduate education and (b) communication with colleagues that may result in recommendations related to teaching and learning; the current study is aimed at adding to the existing literature in this latter kind of on the job learning opportunities.

Third, current scholarly output suggests the benefits of peer-coaching in regard to knowledge spread and promotion of teaching change. Frank, Zhao, and Borman (2004) explain that certain social interactions such as "advice seeking" foster the dissemination of learning and knowledge; Bryk, Camburn, and Louis (1999) highlight that institutions that have their own spaces of collaboration are successful at enhancing change within their teaching practices. Thus, it is inferred that an alternative like peer-coaching could eventually bring about change in the participants' practices that benefit their professional growth. Fourth, the language center where this intervention took place has extensively advocated for a policy of formative assessment of students which could be extended to teachers as well. Peer-coaching could be a strategy of ongoing teachers' evaluation that is non-supervisory, non-judgmental, and very enriching. Last but not least, teachers, in general, would greatly benefit from this experience as observing other teachers' classes enhances reflection about one's own practices and serves the social purpose of strengthening the bonds of friendship (Richards \& Farrell, 2005).

\section{Literature Review}

\section{Peer-Coaching}

Peer-coaching should be seen as an opportunity to learn from colleagues. As stated by Lieberman (1995), oftentimes activities such as experiencing, creating, and problemsolving are thought to boost students' learning. However, these opportunities are not always allowed for teachers. Frequently, workshops count as training but unfortunately, learning from colleagues does not. What Lieberman highlights is the need for getting involved with colleagues to talk, think, try, and refine ideas. In a similar vein, Murray (2010) defines peercoaching as a collaborative endeavor in which participants see themselves as equals. Thus, a peer-coach is a "partner who offers constructive criticism in a non-judgmental way" (Murray, 2010, p. 7). Slater and Simmons (2001) conceive of peer-coaching more as a process through which "professional colleagues work together to reflect on current practices; expand, refine, 
and build new skills; share ideas, teach one another; conduct classroom research; or solve problems in the workplace" (p. 68).

The study of peer-coaching dates back to the 80s when poor implementation of inservice training strategies was spotted (Showers \& Joyce, 1996). As few as $10 \%$ of the teachers carried out ideas they had studied in training sessions. Showers and Joyce's (1996) study defined peer-coaching as a technique in which teachers "shared aspects of teaching, planned together, and pooled their experiences" (p. 14). Such a practice proved to be effective provided that participants often implemented skills and strategies compared to teachers who worked alone.

Another study by Sparks and Bruder (1987) showed that peer-coaching bettered collegiality and encouraged teachers to try new practices. Two schools (41 teachers in all) joined a peer-coaching process. Teachers learned to observe, record events, and give feedback on selected topics such as lesson design, motivation, and active participation. Participants selected three colleagues and met to review the process and the video-taped lessons. Sparks and Bruder evaluated their implementation by asking teachers to complete rating scale questionnaires before and after the project, and 36 teachers were interviewed by an outside evaluator. After applying peer-coaching, the percentage of teachers who rated advice from other teachers as "very helpful" grew from $52 \%$ to $75 \%$. Collegiality also increased in that there was more sharing of ideas and discussion of instruction in the lounge, halls, and lunch time. Finally, experimentation of ideas/strategies increased from $54 \%$ (before peercoaching) to $70 \%$ (after peer-coaching). Through this study, teachers concluded that having a professional colleague as a partner fostered a supportive climate and a sense of trust before any observation took place.

A study by Kohler, Crilley, Shearer, and Good (1997) examined the impact of peercoaching on four teachers' acclimation of an instructional innovation. Teachers applied a new approach, later with an experienced peer-coach and then alone again. Researchers examined organization of activities, types of academic materials, tasks and teachers' directions for students. An analysis of teachers' academic talk, students' engagement and interaction was also carried out. Teachers participated in collaboration meetings with their peer-coaches and identified areas to tackle. The authors concluded that the four teachers, who were involved in the process, carried out "procedural refinements" to their lessons as a result of the collaboration process they experienced while doing peer-coaching. The authors highlight that "reciprocal observation is preferred because it preserves their co-equal interactions and relations" (Kohler et al., 1997, p. 248).

In short, peer-coaching as a strategy to foster improvement in teachers' pedagogical practices proved to be effective as was shown in the studies described above. The major 
items highlighted by the studies reflect an impact on collegiality, more implementation of pedagogical strategies, and a sense of collaboration among colleagues.

\section{Research Design and Implementation}

The inquiry took place at a private university setting where the language center offers its services. The participants of this project were three teachers, each with more than three years of experience working in a university context who wanted to participate. Thus, participants were selected upon convenience (Merriam, 1998) and I played the role of observer.

The participants learned the concept of peer-coaching, developed an understanding of Kolb's ${ }^{1}$ (1984) model of experiential learning, and were asked to choose the foci of the observation for their classes (see Appendix 1). They learned the concept of narratives as data were collected through two narratives. They were asked their background and the experiences they recalled being observed before and after peer-coaching. Table 2 summarizes the different stages of the peer-coaching process the teachers experienced.

Principles of qualitative descriptive research were followed and some characteristics of action research were considered: A problematic situation was found and a way to solve it was proposed, carried out, and evaluated (Burns, 1999). Naturally occurring data were gathered and data collection was systematic. Interpretations emerged from the data. One expert in narrative analysis and one expert in research proofread the instruments used to ensure clarity and coherence with the research question. The narratives as well as the peer-coaching activities were piloted with another teacher to ensure the trustworthiness of the results and to make adjustments in the wording of the narratives prompts. Data were collected in three specific moments: before, while, and after peer-coaching.

Kolb, Boyatzis, and Mainemelis (2001) describe experiential learning as the path one follows to create knowledge by reconstructing one's own experience. I reflected that as part of the implementation teachers could get familiar with the concept of experiential learning developed by Kolb (1984) as the participants were going to develop a learning encounter going from a concrete experience to an abstract understanding of it. Thus, Kolb's (1984) steps of concrete experience, reflective observation and abstract conceptualization were followed by teachers when developing the 3 stages of the project (observation, feedback, reflection). 
Table 2. Steps of the Implementation

\begin{tabular}{|c|c|c|c|c|}
\hline Phase & $\begin{array}{l}\text { Phase } \\
\text { name }\end{array}$ & General activity & Specific activity & $\begin{array}{c}\text { Data collection } \\
\text { instrument used in this } \\
\text { phase }\end{array}$ \\
\hline 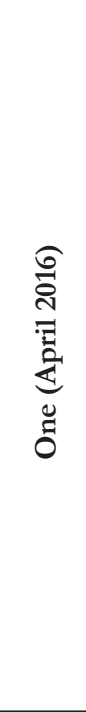 & 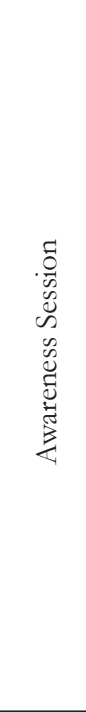 & $\begin{array}{l}\text { Overview of the } \\
\text { peer-coaching } \\
\text { technique }\end{array}$ & $\begin{array}{l}\text { a. Participants select a peer- } \\
\text { coach and area to focus the } \\
\text { observation } \\
\text { b. Assignment: Teacher's } \\
\text { narrative of his/ } \\
\text { her background and } \\
\text { previous experience with } \\
\text { observation-feedback. } \\
\text { c. Teacher-researcher } \\
\text { familiarizes participants } \\
\text { with different definitions } \\
\text { of peer-coaching. } \\
\text { d. Researcher explains to } \\
\text { teachers Kolb's (1984) } \\
\text { model of experiential } \\
\text { learning (pre-observation } \\
\text { talk, observation, feedback) }\end{array}$ & $\begin{array}{l}\text { 1. Teachers' narrative } 1 . \\
\text { Teachers describe } \\
\text { their experience with } \\
\text { previous observation } \\
\text { and feedback (see } \\
\text { Appendix 2). }\end{array}$ \\
\hline 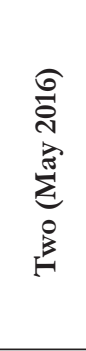 & 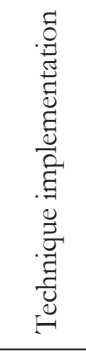 & $\begin{array}{l}\text { Implementing } \\
\text { the peer-coaching } \\
\text { technique }\end{array}$ & $\begin{array}{l}\text { a. Participants select } \\
\text { observation targets and } \\
\text { explain their choice of } \\
\text { focus. } \\
\text { b. Participants carry out class } \\
\text { observation of the targets. } \\
\text { c. Participants have post- } \\
\text { observation talks. }\end{array}$ & $\begin{array}{l}\text { 1. Class observation } \\
\text { form } \\
\text { 2. Audio-recordings } \\
\text { of peer-coach and } \\
\text { teachers' post- } \\
\text { observation talks. }\end{array}$ \\
\hline 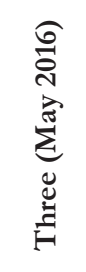 & 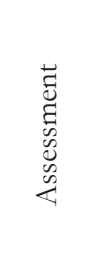 & $\begin{array}{l}\text { Evaluating the } \\
\text { impact of the } \\
\text { peer-coaching } \\
\text { technique }\end{array}$ & $\begin{array}{l}\text { a. Participants write down } \\
\text { a narrative in which they } \\
\text { describe the experience of } \\
\text { participating in the process. }\end{array}$ & $\begin{array}{l}\text { 1. Teachers' narrative } 2 \text {. } \\
\text { Teachers describe } \\
\text { their perceptions } \\
\text { and insights about } \\
\text { being observed and } \\
\text { coached by a peer. } \\
\text { (see Appendix 2) }\end{array}$ \\
\hline
\end{tabular}


The participants were Orlando, Jeison, and Alberto (pseudonyms). They have 20, 6, and 7 years of experience (respectively) teaching children, teenagers, and adults. This inquiry took place when they were teaching general English to students majoring in different areas at a private university in Bogotá, Colombia. Before the three teachers visited each other's class, they received a form to select what aspects of the class they wanted their peers to focus on as suggested by Malu (2015) and Richards and Farrell (2015). I also drew on Richards (2012) to define what pedagogical reasoning referred to in the context of the inquiry (see Appendix 1). After selecting the observation foci, the three participants arranged when to visit a class based on schedule convenience and teacher's time availability. The order of visits and conversations was as follows: Teacher 1 visited Teacher 2, Teacher 2 visited Teacher 3, and Teacher 3 visited Teacher 1. Participants had post-observation talks (in the same order as the visits) which were recorded and transcribed. The instruments use is summarized in Table 3. For systematizing the data collected, I followed the procedure of open coding explained in Charmaz (2006).

Table 3. Instruments Use

\begin{tabular}{|l|l|l|}
\hline \multicolumn{1}{|c|}{ Question } & \multicolumn{1}{c|}{ Instrument } & \multicolumn{1}{c|}{ Unit of analysis } \\
\hline What are teachers' perceptions & Narrative 1 (Before) & Statements that account \\
regarding class observation & Narrative 2 (After) & for reactions towards \\
and feedback before and after & Transcription of post & peer-coaching. \\
participating in peer-coaching? & visit conference & \\
\hline
\end{tabular}

\section{Findings}

\section{Experiencing Observation and Feedback}

In teacher-led professional development activities teachers participate by showing their needs, perceptions, and beliefs. Similarly, the idea of identity is paramount because teachers construct their beings in interactions with others and by reflecting and acting (Mora, Trejo, \& Roux, 2014). In this particular case, the way teachers perceived the basic stages of peercoaching, peer-observation, and peer-feedback depended on various issues; they are: (a) previous knowledge based on teachers' practicum and experience as learners, (b) previous professional experience, (c) their ability to incorporate into their practical knowledge standardized practices of teaching, (d) their lived experiences with supervision practices that intend to regulate how they teach in their particular professional community, and (e) their own sense of who they are as teachers.

Before the intervention, three main approaches to classroom observation and feedback were identified: first, a cautious approach which acknowledges that observation and feedback 
have positive effects only if teachers' own essence is valued; a second approach regarding the contending nature of observation and feedback in the person's self: acknowledgement of self-criticism and awareness of one's strengths. A third highly positive perception about observation and feedback also appeared to conceptualize them as useful. After the intervention, the idea of observation-feedback was related to high anxiety, intimidation, and self-improvement by two participants and as source of "a deep sense of self" by the third participant. These different perspectives evidence how complex the perceptions about observation and feedback are. The sub-categories are described in depth below. Table 4 shows the research question and the emerging category and sub-categories.

Table 4. Research Question, Categories, and Sub-categories

\begin{tabular}{|l|l|l|}
\hline \multicolumn{1}{|c|}{ Research Question } & \multicolumn{1}{c|}{ Category } & \multicolumn{1}{c|}{ Sub-categories } \\
\hline $\begin{array}{l}\text { What are teachers' } \\
\text { perceptions regarding class } \\
\text { observation and feedback } \\
\text { before and after participating } \\
\text { in peer-coaching? }\end{array}$ & $\begin{array}{l}\text { Experiencing } \\
\text { Observation } \\
\text { and Feedback }\end{array}$ & $\begin{array}{l}\text { Before peer-coaching: Three different } \\
\text { approaches towards observation/feedback }\end{array}$ \\
\cline { 2 - 3 } & $\begin{array}{l}\text { After peer-coaching: Two } \\
\text { perspectives towards "the self" }\end{array}$ \\
\hline
\end{tabular}

\section{Before peer-coaching: Three different approaches towards observation/} feedback. Orlando: Cautious approach to observation and feedback. Orlando (20 years of teaching experience) takes a stance as a teacher and former teacher-supervisor. He thinks that observation and feedback are rewarding processes because he has felt part of other teachers' professional growth and learned from them as well. He explains that teachers are willing to receive ideas from others if their own "essence" and teaching styles are acknowledged. In this respect, he explains:

That experience has been rewarding not only because as an observer I have felt part of their professional growth, but also because through those observations I have had the chance to learn new ideas that have enriched my classes. Although it is not easy to give feedback to others since not everyone is willing to receive it, some peers feel comfortable and appreciate the comments you give to identify mistakes they can make and that are not easily perceived when teaching their own classes. Also, teachers might be eager to get ideas from coworkers who have the expertise in some teaching areas as long as they feel their own essence and style in teaching are respected. (Orlando, Narrative 1)

Before peer-coaching, Orlando took a cautious approach towards observation and feedback in the sense that, on the one hand, he acknowledged that one can learn from others 
while observing them. On the other hand, he conditioned the successful result of a process of observation/feedback to the observer's ability to respect the teacher's identity and style.

Jeison: Identity tensions with observations and feedback. Jeison (6 years of teaching experience) describes observation/feedback as crucial for his professional development and acknowledges substantial improvement through them during the last three years especially in the areas of information and communications technologies (ICTs) and strategies to help learners understand language as a system. Still, he finds it hard to comprehend and face mistakes. He highlights two key components when it comes to digesting feedback: selfcriticism and awareness of one's strengths. There appears to be some sort of struggle in him in order to configure himself as an accomplished teacher.

Feedback has been crucial to my professional growth in the last 3 years. I've have had considerable improvement with respect making the most of ICTs in class and implementing strategies to help students internalize and digests language in a more efficient way. The most difficult of getting a detailed feedback is to grasp your flaws and face them with professionalism. It requires self-criticism but also a total awareness of your strengths too. Otherwise you would shatter when the feedback is straightforward and thorough. [sic] (Jeison, Narrative 1)

The process of observation/feedback displays a double edged sword nature in Jeison's case, which consists of a tension between: (a) improvement (through observation/ feedback), (b) his achieved professionalism (awareness of his strengths as a teacher), (c) his acknowledgement of mistakes (spotted by the observer), and (d) his self-criticism (as a teacher). In my view, the tension that Jeison experienced has to do with first, an embedded, perverse belief within our educational culture that observation/feedback has to occur because presumably "teachers always have something to be fixed" (Díaz-Maggioli, 2004, p. 2); what they do is never enough to meet the standards and second, oftentimes, supervisory visions of observation/feedback restrain teachers' ownership of their class. Thus, after observation and feedback, Jeison managed to reconfigure his professional identity: his way of relating to his work, his way of belonging to this professional community by convincing himself that he is a good teacher and by negotiating his understanding of the observation/ feedback result.

When [feedback] was pretty negative, I used to feel extremely disappointed, and kind of confused about why was really that bad. Nonetheless, after quite a few feedback sessions, I've learnt how to identify what the main class aspects to improve for future observations are. After persuading myself that I'm an accomplished teacher, and pulling myself together, I've always been able to undertake the improvements and the latest feedback results have been quite positive. (Jeison, Narrative 1)

Alberto: Strongly positive about observation and feedback. Alberto (7 years of teaching experience) describes observation/feedback as something "fruitful". He refers to supervisors 
as being supportive and good advisors. Observation-feedback appears to be a way to boost his performance in class. He says he has not felt criticized but instead has had the chance to discuss how to do better.

The experience has been fruitful due to the fact that they have been supportive and have tried to give the best recommendations for me to enhance my performance in my classes. I think there is always chance to polish the way I teach classes since every population is different and I have to arrange and rearrange styles, activities, etc. (Alberto, Narrative 1)

This theme suggests that teachers are different in how they approached the professional experience of observation-feedback. For some teachers, observation-feedback might be something that enhances their teaching practices; for others, it is a source of identity tension or an experience that helps accommodate beliefs about oneself. Aligned with Peel (as cited in Weller, 2009) what this first part foretells or reveals is that the instrumental nature of observation can be overcome if the observed teacher gives his or her own meaning to the act of observation and cultivates a capacity for self-reflection on what the observation-feedback entails for them.

After peer-coaching: Two perspectives towards "the self". After participating in peer-coaching, the three participants highlighted some core issues related to the self. The self relates to their identities; it refers to who they are to others (Benwell \& Stokoe, 2006), who they are as teachers, how they and others construct their being in the world as teachers. Three key issues emerged here in their conceptualization of observation/feedback after being peercoached. They are: high anxiety about self-image, intimidation and self-improvement, and the meaning of observation not taken as criticism but as a way to identify "a deep sense of self".

Orlando and Jeison: Overcoming bigh anxiety about self-image. Orlando describes having felt nervous and anxious because, according to him, other coworkers have high expectations about one's classes. He was also concerned about students' behavior. This is because sometimes teachers spend a lot of time lesson planning but as Orlando said students sometimes might "spoil it". This is seen in their resistance to participate in class activities. He says that in the end he felt well and pinpoints that he went through a lot of effort when designing the parts of the lesson in which the peer-coach had to give feedback about. Orlando says:

After having had my peer observing my class, I would say that I felt a little anxious and nervous, especially in the beginning of that session, due to the fact that a partner usually expects a lot from other colleagues' classes and also because I had no idea how my students would react knowing there was someone else visiting the session. Besides, bearing in mind that the group visited was a level one which is just starting with their English learning process, I did not know if they were going to behave properly and work efficiently. However, after the first fifteen minutes of the class, I felt better especially because of the positive attitude my peer was showing and also because I knew I had planned my session carefully...I felt the class went well and pupils had the chance to 
Exploring English Teachers' Perceptions About Peer-Coaching as a Professional Development Activity of Knowledge Construction

interact with others easily and achieve most of the objectives set for that lesson. Regarding the foci of observation the observer had been asked to concentrate on, I paid more attention to that part when planning my lesson. I was looking forward to listening to his comments to know how to improve those three areas, though. (Orlando, Narrative 2)

Jeison also described a tension towards the peer-coaching seeing it as "intimidating at the beginning" but then he evolved to displaying awareness of positive elements of peercoaching and of his own class:

I have to admit that it may be sort of intimidating at the beginning but once one comprehends it is for the sake of self-improvement, it is more bearable. Among the results of the exercise, I could see some of my practices from another perspective... I could conclude that my classes are not that predictable since activities were varied and that makes the sessions catchy for students. (Jeison, Narrative 2)

Both teachers experienced tension regarding being observed by their peer-coach. Still, when they adjusted to being observed by a colleague the process appeared to go smoothly. In Orlando's case, he tried to give the most of himself and Jeison learned that his classes were not as predictable as he had previously thought. These reactions may show the contingency and the dynamic constitution of identity (Benwell \& Stokoe, 2006). Discursively speaking, the classroom atmosphere provided the chances to move from anxiety to self-assurance. This experience with observation turned out to be positive and consequently helped them build self-trust as found in Blackwell and McLean (as cited in Weller, 2009).

Alberto: Observation is not criticism but identifying a deep sense of self. Alberto explains that it is important for him to forget previous ideas of observation as a source of mere criticism. He noticed that "a peer can act as a facilitator". He sees a double identity here not only as someone who knows (teacher) but also as somebody who can get new understandings (learner). Alberto felt "heightened self-awareness" as he could see his class from another's perspective. Actually, he mentions the theme of identity when he says that with feedback he identifies a deep sense of self in regard to himself as a teacher and as a person.

After the class observation and the meeting, what I can see is that I have to forget the old-fashioned model that teachers who observed other teachers' classes were to criticize and not support. What I saw after the process is that a peer can act as a facilitator which means that a peer can assist and support the work of other teachers. In addition, I can act as a teacher/learner due to the professional development services I can receive from my peer (suggestions, tools, etc.). Finally, my peer acts as a collaborative problem-solver who thoroughly addresses class concerns and highlights strengths from my performance. My perceptions are that there is heightened self-awareness since a peer can point out what I cannot see during a class time and make me reflect upon it. Then, I would say that there is better reception and use of feedback due to the ability to identify challen- 
ges and blocks, and a deep sense of self and generally functioning not just as a better teacher but a person, too. (Alberto, Narrative 2)

Alberto, as well as Orlando in Narrative 1, highlights the fact that having a peer in one's class allows us to see the class from another perspective. In a similar vein, the data also suggest that the peer-coaching technique lessens the anxiety that other observations practices exercise as seen in the next excerpt from Orlando and Jeison in their post visit conference:

Orlando: Okay Jeison, so let's... First of all, I would like to ask you how you felt doing this exercise, I mean like this first part of this exercise.

Jeison: Actually, I didn't feel that pressure because I knew that it wasn't involved my actual work. So I felt more confident and I feel more relaxed and I tried to...to teach a class the way I usually do it. [sic] (Transcription of post-observation talk 1)

The previous dialogue also backs up previous research in the topic of peer-coaching in that a sense of collegiality (Sparks \& Bruder, 1987) is fostered when discussing each other's classes.

\section{Discussion}

This peer-coaching experience evidenced how the traditions of teachers' development and education explained by Díaz-Maggioli (2012), those of looking and learning, thinking and learning, participating and learning simultaneously come to play a role in the real world. Peercoaching, to a great extent, involves these perspectives of teachers' learning and that is one of the potentials that it has. Similarly, a fresh perspective towards its use emerged; while the literature suggested peer-coaching as a way to collaboratively learn from others (Lieberman, 1995; Murray, 2010), also as a way to "affirm one's own practices", or "learn new strategies from feedback" (Graham \& Oliver, 2012, p. 6), tensions with observation and feedback were pinpointed by the participants. Professional identity reflections also emerged showing that teachers continuously negotiate who they are even when apparently more horizontal interactions occur.

Similarly, while undergoing this teacher initiated experience, I realized how much knowledge teachers have that is sometimes underestimated and not made visible. I think it is important to make visible the knowledge that teachers accumulate, develop, or construct with others. This inquiry entails that peer-coaching is much more than a technique to enhance professional development to counterbalance supervision practices. It is a space to explore the ecology of teachers' knowledges (de Sousa Santos, 2007, 2009) through the dialogues teachers have about their classes. This realization stems from analyzing one post- 
visit talk between Jeison and Alberto. Through this dialogue, methodological, institutional, and personal knowledges are seen:

Jeison: And also I wanted to highlight well, in, in the part of the grammar, the, the part you were having, having them create like a grammar chart somehow and at the end you elicit the examples, the rules, the structures, uhh...so my question is why did you decide to do it this way?

Alberto: the, the way that...first the, the, the, the, they took the papers they recycled the information, is... because uh, I wanted to check if they, they had, they had done the class preparation, right? They compared if they had understood what they did and then recycle like a part of the assessment alright? Grammar assess, grammar assessment.

Jeison: oh right, that was, so assessment was the...

Alberto: to check if they understood or not, take into account the use, the structure, etc. etc. and they, they were expected to give and to provide a kind of information examples, etc. etc.

Jeison: yeah, I ask you because I face like the same dilemma, sometimes when I do that, I feel that I, uh, I don't know, increase the speaking, the, the teacher speaking time, and from, I don't know, from a different point of view it could be like a little bit teacher-centered so what I decided to do is uhm...ok, have we have, we are applying the strategy of "creating your own grammar chart", you complete the grammar chart but then I show you a slide, I show them an slide with the grammar chart finished or an example that some I rese, resemble the work that they have done and... doing that, we probably save time and, avoid the part in which I have to go to the board and speak and listen and that part in which maybe, probably uh...becomes like teacher-centered, what do you think?

Alberto: well, it could be yeah, but, ehm, I don't know if, if, you notice that the idea was not to explain the grammar but is just to recycle a kind of information, etc. eh, of course I try to help, help them eh, write, write some kind of examples, etc. etc. but yeah, sure I try to eh, uh, I, I try to like ah force them right? To, to give me the most of the information that was expected for the gram, for the assessment, purposes of the grammar chart.

Jeison: oh, right.

Alberto: that was the, that was the idea.

Jeison: oh, right, so the assessment was somehow implicit so probably, I, I, I didn't notice but was my mistake. 
Alberto: exactly, I, I, I, I didn't want, I didn't want to explain the grammar chart but just to recycle the information and try to help them, eh...check what they have or haven't understood from that, from that chart.

Jeison: like, like group assessment

Alberto: exactly.

Jeison: ah ok, and at the end you used something like uh well something there's a detail that I'm am overlooking and it's what you used, to using that reports, using the foamy ball to mingle them to have them interact, I haven't figured out how to use the foamy ball with adults, but you, you told me how. And I want to mention something, something I was relating to the way you assess the objectives at the end of the class using...cards which I think is an amazing idea and is very like, interactive, and it's not like the, the uh common yes/no question at the end; it's more engaging and I like very much. So, I want to ask you: where did you get the idea?

Alberto: Actually, that was one of the, the tools that some of the, of my professor from, uh, uh, from the masters, and actually for my, for my uh degree ask me to use, alright, and there are many sources that you are going to use like a part of assessment. [sic]

This excerpt shows mostly Alberto's canonical knowledge of English teaching methodology and pedagogical principles which, to some extent as he expressed, comes from his MA studies, and probably from the philosophy of the institution he works for. He displays his knowledge of classroom techniques to grasp students' responses like eliciting questions, asking for homework. His teacher's knowledge concerning learning strategies is evidenced in his use of checking understanding, recapitulating ("recycling" previous knowledge from learners). He also holds the idea that knowledge of the student ought to be assessed. That is, there is need to check how much the students have learned based on the creation of students own grammar chart. Concerning Jeison, he holds the idea that the classroom is an opportunity for students to speak and thus, he is concerned with his teaching talking time. His pedagogical knowledge suggests that in the lesson he should minimize teachercenteredness.

From these participants' conversation, it could be concluded that they held a view of knowledge that could be considered constructivist in that a teacher is focused on students' understanding and preparation of their own examples. He also avoided taking over the class as the only knowledgeable agent. Here, some personal theories intertwined with canonical knowledge of English language teaching are seen. Thus, an experience of peer-coaching goes beyond the mere dialogue intended to improve practices and comes to be a space to explore teachers' knowledge in action. 


\section{Conclusion}

The results of this small-scale action research suggest that teachers' perceptions regarding class observation and feedback before and after participating in peer-coaching are framed as follows: before peer-coaching, one perception was that of being cautious concerning observation/ feedback in the sense that although they can be used as a process to learn, the observer must be respectful of the expertise of the teacher being observed. Another perception was that of observation/feedback considered as a source of improvement, professionalism, and reflection about one's own actions through another's eyes. On the other hand, observation/feedback was also taken as a threat to the teacher's professional identity. The last perception identified in the first part was observation/feedback as a way to enhance teachers' performances. After using peer-coaching, two perceptions regarding observation/feedback were identified: One that dealt with teacher identity tensions regarding self-image, intimidation, and self-improvement and the other that has to do with observation/feedback as means to understand one's own self as teacher.

\section{Implications for Further Projects}

Developing this small-scale action research project suggests that the exploration of professional development activities (here, peer-coaching) have deeper meanings compared to what is presented at the surface level of these techniques implementation. Professional development activities are frequently aimed at improving teaching practices and not as ways in which teachers can socialize their existing knowledge or their own constructions of theories and in-situ understandings. Thus, the reflections framed here open a window to the exploration of other techniques (e.g., lesson study, journaling, analysis of recorded lessons) from the perspective that teachers are knowledgeable beings and what they think, do, and say through these techniques may contribute to the exploration of their distinctive ways of knowing (Kumaravadivelu, 2012). Finally, it is valuable to highlight that teacher-initiated actions may result in greater benefits for themselves and for the community involved in the educational practices. When teachers carry out their own processes of reflection, changes may occur as a result the agency exercised by teachers.

\section{References}

Benwell, B., \& Stokoe, E. (2006). Discourse and identity. Edinburgh, UK: Edinburgh University Press.

Bryk, A. S., Camburn, E., \& Louis, K. S. (1999). Professional community in Chicago elementary schools: Facilitating factors and organizational consequences. Educational Administration Quarterly, 35(5), 751-781. http://doi.org/10.1177/0013161X99355004.

Burns, A. (1999). Collaborative action research for English language teachers. Cambridge, UK: Cambridge University Press. 
Charmaz, K. (2006). Constructing grounded theory: A practical guide through qualitative analysis. London, UK: Sage Publications.

de Sousa Santos, B. (2007). Beyond abyssal thinking: From global lines to ecologies of knowledges. Review, 30(1), 45-89.

de Sousa Santos, B. (2009). Una epistemología del sur [An epistemology of the South]. Mexico: CLACSO Coediciones.

Díaz-Maggioli, G. (2004). Teacher-centered professional development. Alexandria, US: Association for Supervision and Curriculum Development.

Díaz-Maggioli, G. (2012). Teaching language teachers: Scaffolding professional learning. New York, US: Rowman \& Littlefield Education.

Frank, K. A., Zhao, Y., \& Borman, K. (2004). Social capital and the diffusion of innovations within organizations: The case of computer technology in schools. Sociology of Education, 77(2), 148-171. http://doi.org/10.1177/003804070407700203.

Gallucci, C., Van Lare, M. D., Yoon, I. H., \& Boatright, B. (2010). Instructional coaching: Building theory about the role and organizational support for professional learning. American Educational Research Journal, 47(4), 919-963. http://doi.org/10.3102/0002831210371497.

Graham, H., \& Oliver, G. (2012). Seeing is believing: The benefits of peer observation. Journal of University Teaching \& Learning Practice, 9(1), 1-9. Retrieved from http://ro.uow.edu.au/jutlp/vol9/iss1/7.

Hişmanoğlu, M., \& Hişmanoğlu, S. (2010). English language teachers' perceptions of education supervision in relation to their professional development: A case study of Northen Cyprus. Novitas-Royal Research on Youth and Language, 4(1), 16-34.

Kohler, F. W., Crilley, K. M., Shearer, D. D., \& Good, G., (1997). Effects of peer coaching on teacher and student outcomes. The Journal of Educational Research, 90(4), 240-250. http:/ doi. org/10.1080/00220671.1997.10544578.

Kolb, D. A. (1984). Experiential learning: Experience as the source of learning and development. Upper Saddle River, US: Prentice Hall.

Kolb, D. A., Boyatzis, R. E., \& Mainemelis, C. (2001). Experiential learning theory: Previous research and new directions. In R. J. Sternberg \& L. F. Zhang (Eds.), Perspectives on thinking, learning, and cognitive styles (pp. 227-247). New Jersey, US: Lawrence Erlbaum.

Kumaravadivelu, B. (2012). Language teacher education for a global society: A modular model for knowing, analyzing, recognizing, doing, and seeing. New York, US: Routledge/Taylor and Francis.

Lieberman, A. (1995). Practices that support teacher development. Phi Delta Kappan, 76(8), 591-596.

Malu, K. F. (2015). Observation tools for professional development. English Teaching Forum, 53(1), 14-24.

Merriam, S. B. (1998). Qualitative research and case study applications in education. San Francisco, US: Jossey-Bass Publishers.

Mora, A., Trejo, P., \& Roux, R. (2014). English language teachers' professional development and identities. PROFILE Issues in Teachers' Professional Development, 16(1), 49-62. http://dx.doi. org/10.15446/profile.v16n1.38153. 
Murray, A. (2010). Empowering teachers through professional development. English Teaching Forum, 48(1), 2-11

Norton, B. (1995). Social identity, investment, and language learning. TESOL Quarterly, 29(1), 9-31. http://doi.org/10.2307/3587803.

Parise, L., \& Spillane, J. (2010). Teacher learning and instructional change: How formal and onthe-job learning opportunities predict change in elementary school teachers' practice. The Elementary School Journal, 110(3), 323-346. http://doi.org/10.1086/648981.

Richards, J. C. (2012). Competence and performance in language teaching. In A. Burns \& J. C. Richards (Eds.), The Cambridge guide to pedagogy and practice in second language teaching (pp. 46-56). Cambridge, UK: Cambridge University Press.

Richards, J. C., \& Farrell, T. S. C. (2005). Professional development for language teachers: Strategies for teacher learning. Cambridge, UK: Cambridge Language Education. http://doi.org/10.1017/ CBO9780511667237.

Riessman, C. K. (2008). Narrative methods for the human sciences. Los Angeles, US: Sage.

Showers, B., \& Joyce, B. (1996). The evolution of peer-coaching. Educational Leadership, 53(6), 1216.

Slater, C. L., \& Simmons, D. L. (2001). The design and implementation of a peer coaching program. American Secondary Education, 29(3), 67-76.

Sparks, G. M., \& Bruder, S. (1987). Before and after peer coaching. Educational Leadership, 45(3), 54-57.

Weller, S. (2009). What does "peer" mean in teaching observation for the professional development of higher education lecturers? International Journal of Learning and Teaching in Higher Education, 21(1), 25-35.

\section{The Author}

Adriana Castañeda-Londoño holds an MA in Applied Linguistics from Universidad Distrital Francisco José de Caldas (Colombia). She is currently pursuing doctoral studies in education with an emphasis in ELT at the same university. Her research interests are discourse studies within education; teachers' professional development; ecologies of knowledges; poststructuralist, postcolonial, and decolonial studies in ELT. 


\section{Appendix 1: Form to Select the Foci of Observation}

\section{Teacher's name:}

Richards (2012) states that teachers' pedagogical reasoning and teaching skills refer to the acquired knowledge teachers have gotten through experience, content knowledge, and observation of learners. It is a complex set of abilities to be able to turn the subject matter (in this case English) into forms that are appropriate for learners. This set of abilities comprises analyzing the potential of lessons, anticipating problems that may occur, making appropriate decisions about pace, time, sequencing, or grouping.

Select 2 items of "pedagogical reasoning" and "teaching skills" that you want to receive feedback about from you peer-coach and explain the reason why next to the item.

1. Teacher-student interaction and rapport (How's the interaction among $\mathrm{T}$ and SS? How are teachers' instructions? How's the relationship between T and SS?)

2. Student-student interaction (How's the interaction among SS? How are activities fostering such interaction?)

3. Time, activities sequence and group arrangements (How is the time managed? How is the group arrangement helping learners? How does the teacher sequence his activities?)

4. Teacher's decision-making about lesson delivery (How does the teacher deliver the lesson? How does he favor the learning process?)

5. The use of resources within the lesson (What are the teacher's resources? How are they contributing to the lesson delivery? How's the teacher's use of them?)

6. Other: 


\section{Appendix 2: Teachers' Instructions for the Two Narratives}

Name: College Degree:

MA Degree: Years of experience:

Populations you have worked with and years of experience in each one

\section{What is a narrative?}

Dentith (as cited in Riessman 2008) states that the word narrative can have a different meaning for each discipline in the human sciences. Actually, some people relate it with "story". A person selects a series of sequential events that are important for him/her in a specific topic. Narratives entail ranges from remembering to entertaining. They may argue, justify, persuade, or engage. "Many investigators are now turning to narrative because the stories reveal truths about human experience." (p. 10)

\section{Narrative 1}

Describe what your experience with class observation and feedback has been. Mention experiences, improvements, insights, effects, perceptions, and actions that have been involved in this process.

\section{Narrative 2}

Describe your perceptions and insights about being observed and coached by a peer. 